\title{
Ferronickel slag toxicity tests on Chlorella vulgaris and Artemia sp.
}

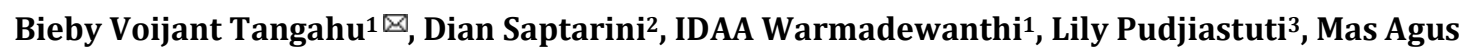 \\ Mardyanto Tardan ${ }^{1}$ and Arif Luqman ${ }^{1}$
}

\begin{abstract}
Acute effects of ferronickel slag toxicity on Chlorella vulgaris and Artemia sp. were studied. Tests were conducted on ferronickel slag to determine the concentration of heavy metals leached out to the environment. Toxicity tests were also carried out on the organisms with minimum exposure duration of 4 days or until the occurrence of a negative effect. About 400 cells $\mathrm{mL}^{-1}$ of $C$. vulgaris and 20 individuals of Artemia sp. were used in each of the reactors with media containing slag concentration ranged from 0 to $50 \%$. Results showed that the IC50 (inhibition concentration) value of the percentage of slag $(\mathrm{w} / \mathrm{v})$ for $C$. vulgaris was $5-10 \%$. Slag toxicity test on Artemia showed that LC50 (lethal concentration) for the percentage of slag was also between $5-10 \%$. The study proved beyond doubt the acute effects of the slag at low concentration $(10 \% \mathrm{w} / \mathrm{v})$ as indicated by the inhibition of growth of $60 \%$ of the $C$. vulgaris population and deaths of more than $50 \%$ of the Artemia in the reactors. Hence the study suggests wise use of the slag to avoid disturbances to environment and society at large.
\end{abstract}

Keywords: Artemia; Chlorella vulgaris; ferronickel slag; heavy metal; toxicity

Received: 22 March 2014 / Accepted revised version: 4 July 2014 / Published online: 15 August 2014

(C) Horizon e-Publishing Group

CITATION

Tangahu, B. V., Saptarini, D., Warmadewanthi, I., Pudjiastuti, L., Tardan, M. A. M., \& Luqman, A. (2014). Ferronickel slag toxicity tests on Chlorella vulgaris and Artemia sp. Plant Science Today, 1(3), 155-160. http://dx.doi.org/10.14719/pst.2014.1.3.29

AUTHORS' AFFILIATIONS

${ }^{1}$ Department of Enviromental Engineering, Institut Teknologi Sepuluh Nopember, Surabaya, Indonesia

2 Department of Biology, Institut Teknologi Sepuluh Nopember, Surabaya, Indonesia

${ }^{3}$ Department of Chemical Engineering, Institut Teknologi Sepuluh

Nopember, Surabaya, Indonesia

CORRESPONDENCE

\Bieby Voijant Tangahu E-mail: voijant@its.ac.id

\section{Introduction}

Slag is one of the by-products of nickel seed processing industry which ultimately converted to ferronickel (Ingots \& Shot). The slag produced in such processes can be as high as 50-75\% (Svana \& Ysteb, 1990). Ferronickel processing industry in Illigan City, Philippines produces up to 500,000 metric tons of slag per year (Demotica, Amparado Jr., Malaluan, \& Demayo, 2012). The slag has been used extensively in some countries possibly due to the omission of the same from the hazardous waste classification. In Illigan Bay, slag is widely being used as a material for reclamation. In the Illawarra and Newcastle, Australia, the slag has been applied as a substitute for cement for several years (Julli, 1999; Demotica et al., 2012).

Indonesian Governmental Regulation No.18 and 85 (1999) regarding hazardous and toxic waste management mentions the slag from the processing of nickel under hazardous waste category. It is due to the presence of high concentrations of heavy metals that are harmful to health of human beings and other organisms (Kozanoglou \& Catsiki, 1997; Tsangaris, Papathanasiou, \& Cotou, 2007; Catsiki, Bel, \& Nicolaidou, 1994). There are several ferronickel industries that will be built in Indonesia. But before commencing any utilization programme, study of the effect of slag on the environment is necessary. Toxicity tests on aquatic marine organisms such as C. vulgaris (single-cell green algae, belonging to the phylum Chlorophyta) and Artemia sp. (aquatic crustaceans known as brine shrimp belongs to the family Artemiidae) will give an idea on the effect of slag on sea environment (Dinesh et al., 2014; Long \& MacDonald, 1998; Smith, Savino, \& Blouin, 1988). In contrast to other studies aimed at understanding toxicity effects of ferronickel slag on any particular group of organisms, the present study aimed at analyzing the same simultaneously on representative plant and animal systems. 


\section{Material and methods}

Toxic Characteristic Leaching Procedure (TCLP) test (US EPA, 1992) was conducted on ferronickel slag to determine the leaching of heavy metals that exceed the quality standard. It is a soil sample extraction method for chemical analysis employed as an analytical method to simulate leaching through a landfill. The testing methodology is used to determine if a waste is characteristically hazardous or not. The toxicity of ferronickel slag on C. vulgaris and Artemia sp. that have been acclimatized previously was conducted where minimum duration of exposure was 4 days or until the occurrence of a negative effect on the organisms. Concentrations (\%) of slag used in the study include 0 (designated as C0), 2 (C1), 5 (C2), 10 (C3), 20 (C4), and 50 (C5). Approximately 400 cells $\mathrm{ml}^{-1}$ for $C$. vulgaris and 20 individuals of Artemia sp. were used in each reactor. Observation of the number of dead organisms was carried out every day and determined no observed effect concentration (NOEC), lowest observed effect concentration (LOEC), and the IC50 (inhibition concentration) for $C$. vulgaris and LC50 (lethal concentration) for Artemia sp.

\section{Results and discussion}

\section{Analysis of TCLP test results}

The TCLP test was conducted on the slag for heavy metals such as $\mathrm{Fe}, \mathrm{Cr}, \mathrm{Cu}, \mathrm{Pb}$, and $\mathrm{Cd}$ (Table 1). The TCLP test indicated that content of $\mathrm{Cr}$ exceeded the quality standard based on Governmental Regulation No.18/1999, which states $0.25 \mathrm{ppm}$ as the maximum levels of $\mathrm{Cr}$ in the waste materials.

Table 1. Comparison of slag TCLP test results and quality standards (Governmental Regulation No.18/1999)

\begin{tabular}{ccc}
\hline Heavy Metals & Slag & Quality standards \\
\hline $\mathrm{Fe}$ & 1586775 & $\mathrm{NL}$ \\
$\mathrm{Cr}$ & 0.645 & 0.25 \\
$\mathrm{Cu}$ & $\mathrm{ND}$ & 0.19 \\
$\mathrm{~Pb}$ & 0.0219 & 2.50 \\
$\mathrm{Cd}$ & $\mathrm{ND}$ & 0.05 \\
\hline
\end{tabular}

Quantity of the heavy metals are expressed in PPM. $\mathrm{ND}=$ Not detected; $\mathrm{NL}=$ Not listed.

\section{Toxicity of ferronickel slag on $C$. vulgaris}

Results of acute toxicity tests on $C$. vulgaris showed that the slag affected the growth of the organism (Fig. 1a). The results clearly showed that the cell density of $C$. vulgaris differ considerably among controls and test samples with varying percentage of slag. The density difference of $C$. vulgaris was observed since the 2 nd day of the experiment. However, almost same density levels were noticed for slag content ranging from 2 to $20 \%$. It was clearly noticed that density of $C$. vulgaris at $50 \%$ of the slag content was significantly lower than that of any other percentage range. This is consistent with the study of Qian et al. (2013) which stated that exposure to $\mathrm{Cr}$ ions can inhibit the growth of $C$. vulgaris.

Exposure to slag affected the density of $C$. vulgaris in the media. Difference in cell density of $C$. vulgaris between the beginning and the last observation day was counted as yield and the difference in percentage of yield between the treatment and control of various slag percentages was calculated as the percent inhibition. The slag toxicity tests determined that the IC50 of the percentage of slag (w/v) on $C$. vulgaris was $5-10 \%$ (Fig. 1b). Tests conducted at slag percentages of $2,5,10,20$, and $50(\mathrm{w} / \mathrm{v})$ resulted into percent inhibition of $30,40,60,80$, and 90 respectively.

Based on the toxicity tests conducted, it was observed that exposure to slag at higher concentration inhibits the growth of $C$. vulgaris. It is because of the heavy metals, especially $\mathrm{Cr}$, present in the slag (Table 1) which exceeded that of the quality standards based on Government Regulation No. 18 of 1999. The $\mathrm{Cr}$ is absorbed into the algal cells which disrupt chloroplast structure and reduce the levels of chlorophyll. Besides, $\mathrm{Cr}$ exposure also can increase the volume of the vacuole that reduces the space for the chloroplast. Eventually, due to reduced chlorophyll content, photosynthesis is inhibited and therefore contributes to reduced growth of $C$. vulgaris (D'ors, Pereira, Bartolome, Lopez-Rodas, Costas, \& Sanchez-Fortun, 2010). In addition, exposure to $\mathrm{Cr}$ ions can also cause structural changes in the cell nucleus that affect the growth of algal symbionts (Licursi and Gomez, 2013).

There are differences in the $\mathrm{Cr}$ content in the media with and without slag which was used to grow $C$. vulgaris. It was noted that the higher the percentage of slag, $\mathrm{Cr}$ content in aqueous media also tends to increase due to leaching (Fig. 2 ). However after growth, the $\mathrm{Cr}$ content in the water was lower than medium without $C$. vulgaris. This suggests that the $\mathrm{Cr}$ leached out from the slag into the media entered into the $C$. vulgaris system and accumulated there so that $\mathrm{Cr}$ content in the aqueous media with $C$. vulgaris was reduced considerably (Fig. 2). The presence of $\mathrm{Cr}$ inside the cell of $C$. vulgaris can cause negative effects, such as reduced rate of photosynthesis and growth disorders.

\section{Toxicity of ferronickel slag on Artemia sp.}

The slag toxicity tests determined that the LC50 of the percentage of slag (w/v) on Artemia sp. was 5-10\% (Fig. 3a and Fig. $3 \mathrm{~b}$ ). When the slag concentration was higher than $10 \%$, death of more than $50 \%$ of the population of Artemia in the reactor was noted. The death of Artemia might be due to acute toxic effects of heavy metals from slag, especially $\mathrm{Cr}$ because based on the TCLP test results of the 


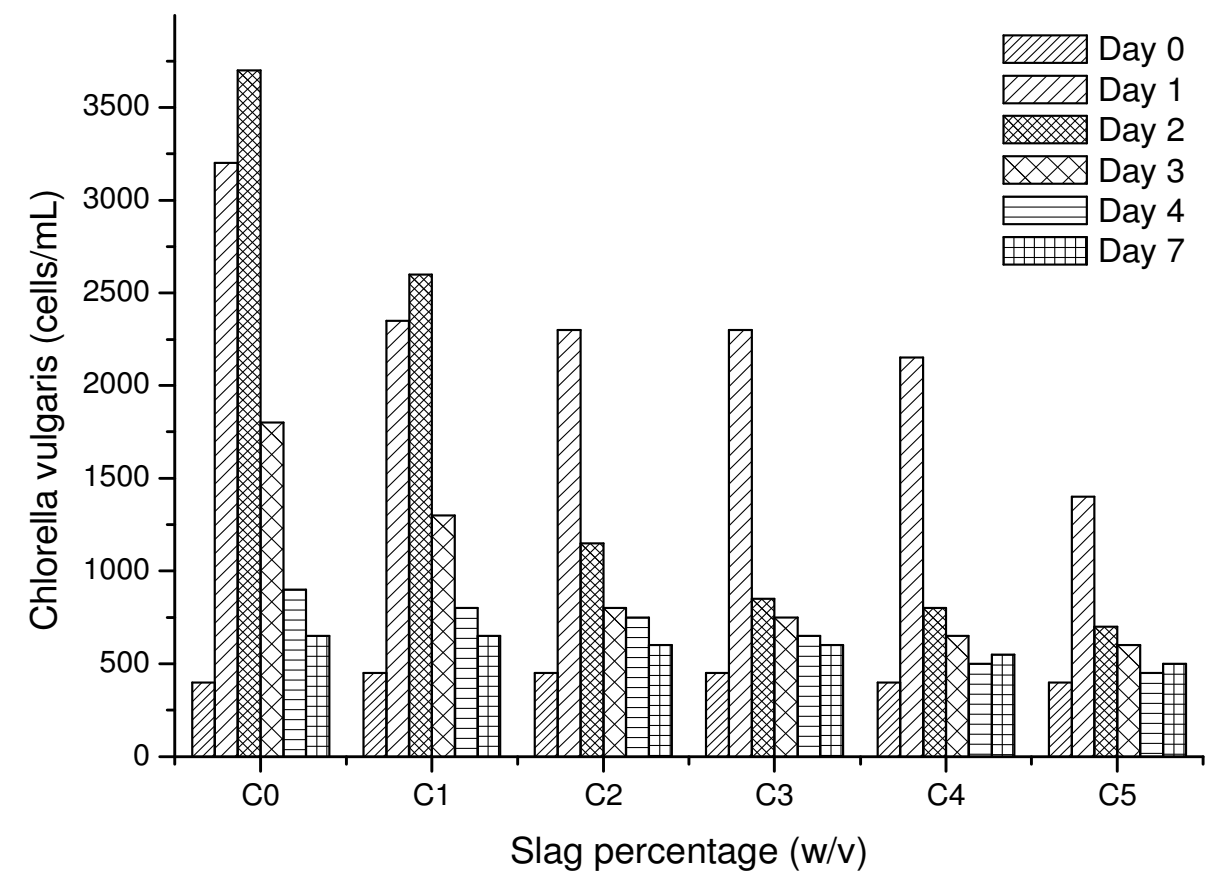

(a)

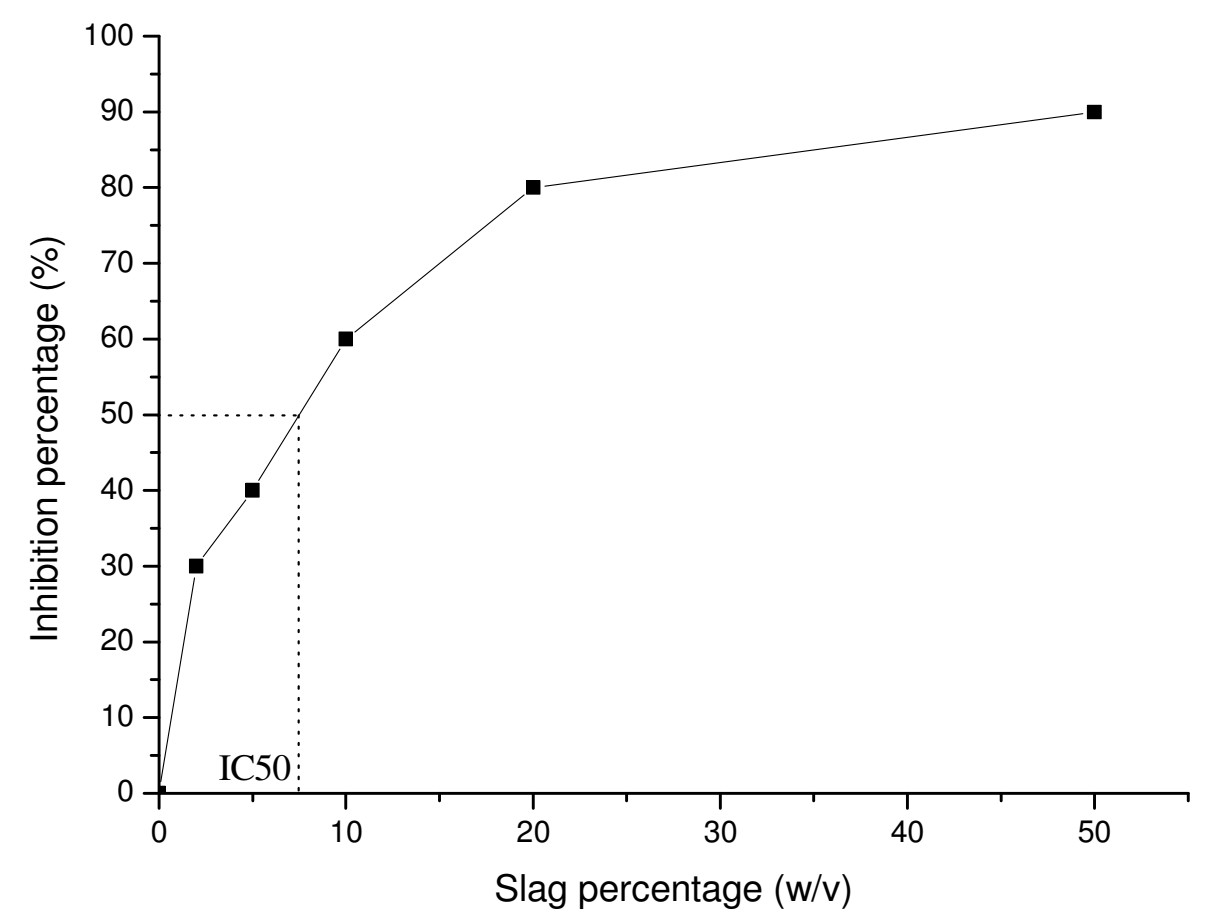

(b)

Fig. 1. Comparison of the effect of slag concentration (w/v) on $C$. vulgaris (a) and the relationship between the percentage of slag $(w / v)$ with the percent inhibition (b).

slag (Table 1), the $\mathrm{Cr}$ content of the slag exceeded the quality standards.

There was difference in $\mathrm{Cr}$ content in the media with and without Artemia. In the graph (Fig. 4) it can be seen that the higher the percentage of slag, $\mathrm{Cr}$ content in aqueous media also tends to increase because the process 


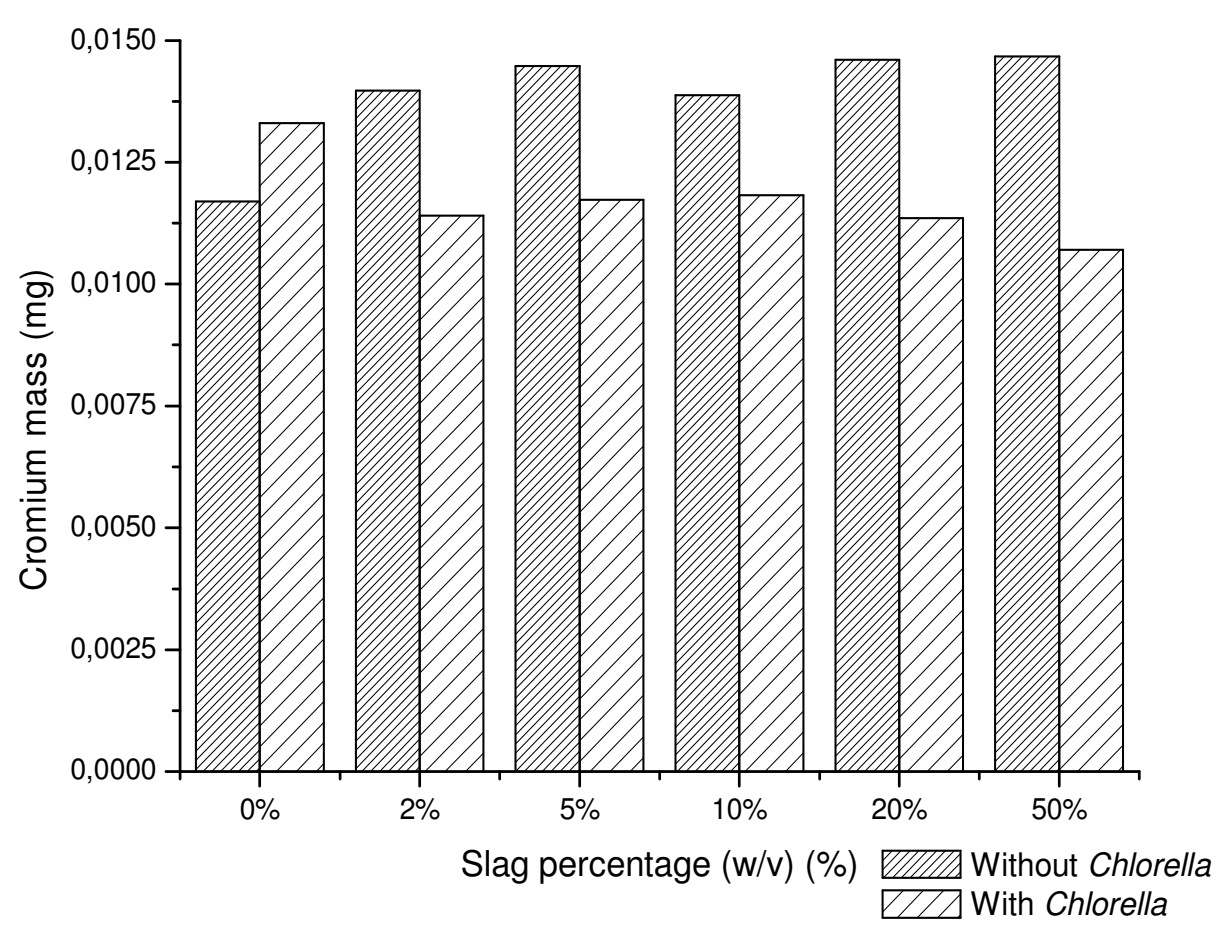

Fig. 2. Comparison of chromium content in medium with and without $C$. vulgaris.

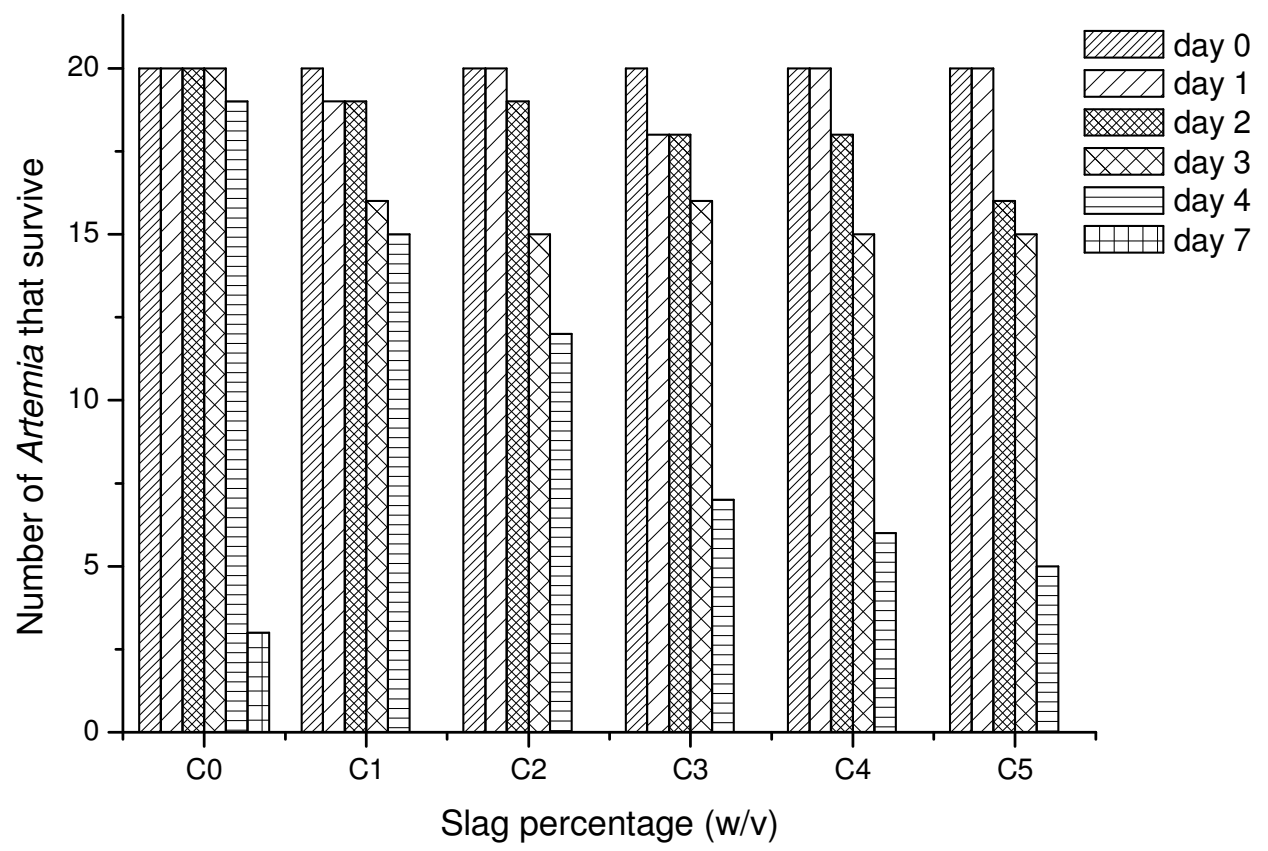

Fig. 3a. Comparison of the effect of slag concentration (w/v) on Artemia

of leaching as noted for C. vulgaris. Comparatively, the $\mathrm{Cr}$ content was lower in aqueous media with Artemia. This indicates that the $\mathrm{Cr}$ entered into the body of Artemia from the water so that the mass of $\mathrm{Cr}$ on media with Artemia was reduced. The presence of heavy metal $\mathrm{Cr}$ inside the body of Artemia can cause negative effects including mortality.

Exposure to $\mathrm{Cr}$ can influence on the survival of population of Artemia which is very sensitive to pollutants. Studies (Verriopoulos, Milliou, \& Moraitou-Apastolopoulou, 1988) found that acute exposure to $\mathrm{Cr}$ can affect physiology of Artemia, mainly 


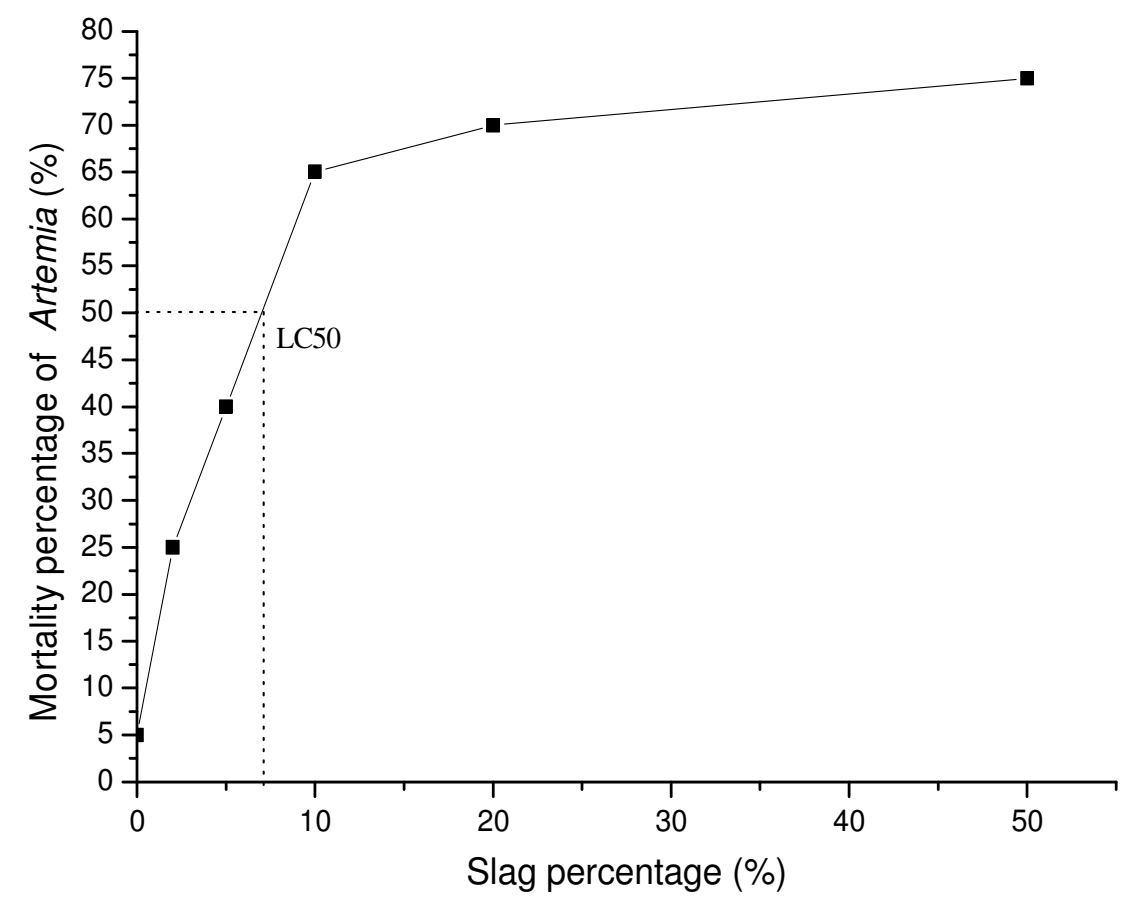

Fig. 3b. The relationship between the percentage of slag (w/v) and percentage mortality of Artemia

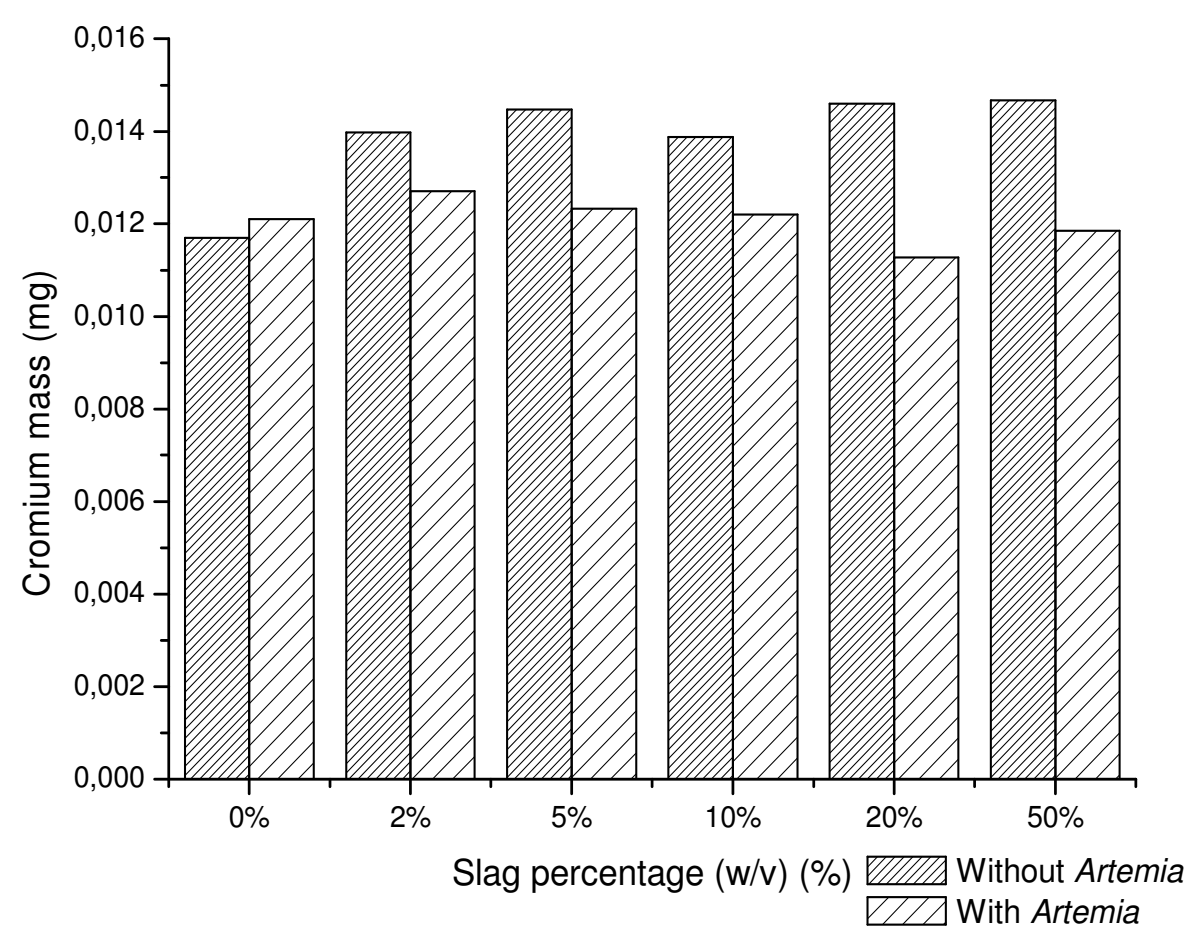

Fig. 4. Comparison of chromium content in medium with and without Artemia

with an increase in the intensity of respiration. In addition, $\mathrm{Cr}$ can also cause destructive oxidative stress that can lead to death of Artemia (Li et al., 2013; Li, Z-H., Li, P., \& Randak, 2011).

\section{Conclusions}

The present study found out that the slag was toxic even at lower concentrations on $C$. vulgaris as inferred from the 
IC50 which was $5-10 \%(\mathrm{w} / \mathrm{v})$. Besides, the slag toxicity test on Artemia showed that the LC50 was also between 5-10\%. Acute effects of slag on Artemia was noted at $10 \%$ of slag $(\mathrm{w} / \mathrm{v})$ indicated by the deaths of more than $50 \%$ of the population of Artemia in the reactor. The treatments caused a dose dependant inhibition of growth. The study clearly showed the effect of slag on marine organisms.

\section{Acknowledgments}

The authors gratefully acknowledge PT. Multi Baja Industri (PT. MBI) Indonesia for fully supporting this research project. They also acknowledge with thanks to Institut Teknologi Sepuluh Nopember (ITS) Surabaya Indonesia for providing all laboratory facilities.

\section{References}

Catsiki, V. A., Bel, F., \& Nicolaidou, A. (1994). Size dependent metal concentrations in two marine gastropod species. Netherland Journal of Aquatic Ecology, 28(2), 157-165. http://dx.doi.org/10.1007/BF02333986

Demotica, J. S., Amparado Jr., R. F., Malaluan, R. M., \& Demayo, C. G. (2012). Characterization and Leaching Assessment of Ferronickel Slag from a Smelting Plant in Iligan City, Philippines. International Journal of Environmental Science and Development, 3(5). http://dx.doi.org/10.7763/IJESD.2012.V3.269

Dinesh, K. S., Santhanam, P., Ananth, S., Devi, A. S., Nandakumar, R., Prasath B. B., ... \& Ananthi, P. (2014). Effect of different dosages of zinc on the growth and biomass in five marine microalgae. International Journal of Fisheries and Aquaculture, 6(1), 1-8. http://dx.doi.org/10.5897/IJFA2013.0393

D'ors, A., Pereira, M., Bartolome, M. C., Lopez-Rodas, V., Costas, E., \& Sanchez-Fortun, S. (2010). Toxic effects and specific chromium acquired resistance in selected strains of Dyctiosphaerium chlorelloides. Chemosphere, 81, 282-287. http://dx.doi.org/10.1016/j.chemosphere.2010.05.051 PMid:20580406

Julli, M. (1999). Ecotoxicity and chemistry of leachates from blast furnace and basic oxygen steel slag. Australasian Journal of Ecotoxicology, 5, 123-132.

Kozanoglou, C., \& Catsiki, V. A. (1997). Impact of products of a ferronickel smelting plant to the marine benthic life, Chemosphere, 34(12), 2673-2682, ISSN 0045-6535, http://dx.doi.org/10.1016/S0045-6535(97)00093-3

Li, M., Zheng, Y., Liang, H., Zou, L., Sun, J., Zhang, Y., ... \& Wang, Z. (2013). Molecular cloning and characterization of cat, gpx1 and $\mathrm{Cu} / \mathrm{Zn}$-sod genes in pengze crucian carp (Carassius auratus var. Pengze) and antioxidantenzyme modulation induced by hexavalent chromium in juveniles. Comparative Biochemistry and Physiology, Part C, Vol. 157, pp. 310-321.

Li, Z-H., Li, P., \& Randak T. (2011). Evaluating the toxicity of environmental concentrations of waterborne chromium (VI) to a model teleost, Oncorhynchus mykiss: a comparative study of in vivo and in vitro. Comparative Biochemistry and Physiology, Part C, Vol. 153, pp. 402-407.

Licursi, M. \& Gomez, N. (2013). Short-term toxicity of hexavalent-chromium to epipsammic diatoms of a microtidal estuary (Río de la Plata): Responses from the individual cell to the community structure. Aquatic Toxicology, 134-135, pp. 8291. PMid:23603145 http://dx.doi.org/10.1016/j.aquatox.2013.03.007

Long, E. R., \& D. D. MacDonald. (1998). Recommended Uses of Empirically Derived, Sediment Quality Guidelines for Marine and Estuarine Ecosystems. Human and Ecological Risk Assessment: An International Journal 4(5).

Peraturan Pemerintah No. 18 tahun 1999 tentang Pengelolaan Limbah Bahan Berbahaya dan Beracun (Indonesian Government Regulation No. 18/ 1999 about Hazardous and Toxic Waste Management).

Peraturan Pemerintah No. 85 tahun 1999 tentang Perubahan Atas Peraturan Pemerintah No. 18 tahun 1999 (Indonesian Government Regulation No. 85/ 1999 about The Revision of Indonesian Government Regulation No. 18/ 1999).

Qian, H., Sun, Z., Sun, L., Jiang, Y., Wei, Y., Xie, J., \& Fu, Z. (2013). Phosphorus availability changes chromium toxicity in the freshwater alga Chlorella vulgaris, Chemosphere. 93(6), 885-891. http://dx.doi.org/10.1016/i.chemosphere.2013.05.035

Smith, S. B., Savino, J. F., \& Blouin, M. A. (1988). Acute Toxicity to Daphnia Pulex of Six Classes of Chemical Compounds Potentially Hazardous to Great Lakes Aquatic Biota. Journal of Great Lakes Research, 14(4), Pp 394-404, ISSN 0380-1330, http://dx.doi.org/10.1016/S0380-1330(88)71572-5

Svana, E., \& Ysteb, R. (1990). Production of FeNi from high iron nickel ores, Engineering Division, Norway.

Tsangaris, C., Papathanasiou, E., \& Cotou, E. (2007). Assessment of the impact of heavy metal pollution from a ferro-nickel smelting plant using biomarkers. Ecotoxicology and Environmental Safety, 66(2), 232-243, ISSN 0147-6513, http://dx.doi.org/10.1016/i.ecoenv.2006.03.011

US EPA. (1992). Toxicity characteristic leaching procedure. http://www.epa.gov/wastes/hazard/testmethods/sw846/p dfs/1311.pdf

Verriopoulos, G., Milliou, E., \& Moraitou-Apastolopoulou, M. (1988). Joint effects of four pollutants (copper, chromium, oil,oil dispersant) on the respiration of Artemia, Archives of Hydrobiology, 3, 475-480.

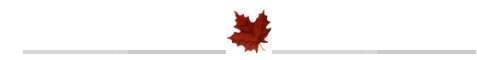

